\title{
Copro-PCR in the detection and confirmation of Toxoplasma gondii oocysts in feces of stray and domiciled cats
}

\author{
Copro-PCR na detecção e confirmação de oocistos de Toxoplasma gondii em \\ fezes de gatos errantes e domiciliados
}

\begin{abstract}
Jaqueline Ataíde Silva Lima da Igreja1* (D); Hanstter Hallison Alves Rezende2; Jade de Oliveira Melo; João Luís Garcia3; Felippe Danyel Cardoso Martins³; Ana Maria de Castro1
\end{abstract}

\author{
'Laboratório de Estudos da Relação Parasito-Hospedeiro, Instituto de Patologia Tropical e Saúde Pública, Universidade Federal de \\ Goiás - UFG, Goiânia, GO, Brasil \\ ${ }^{2}$ Laboratório de Bioquímica Clínica e Líquidos Corporais, Unidade Acadêmica Especial de Saúde, Regional Jataí, Universidade Federal \\ de Goiás - UFG, Jataí, GO, Brasil \\ ${ }^{3}$ Laboratório de Protozoologia Veterinária, Universidade Estadual de Londrina - UEL, Londrina, PR, Brasil
}

How to cite: Lima da Igreja JAS, Rezende HHA, Melo JO, Garcia JL, Martins FDC, Castro AM. Copro-PCR in the detection and confirmation of Toxoplasma gondii oocysts in feces of stray and domiciled cats. Braz J Vet Parasitol 2021; 30(2): e000621. https:// doi.org/10.1590/S1984-29612021022

\begin{abstract}
Molecular methods such as Copro-PCR stand out in the diagnosis of T. gondii because they are highly sensitive and specific, and can distinguish $T$. gondii from other morphologically similar coccids. The purpose was the detection of Toxoplasma gondii copro-prevalence by polymerase chain reaction in 149 fecal samples from stray and domiciled cats, using three distinct markers (B5-B6, $18 \mathrm{~S}$ and 529bp RE). Oocysts of T. gondii/H. hammondi were detected in $15.4 \%$ by parasitology fecal tests (PFT), and $4 \%$ of these oocysts were positively identified as $T$. gondii by Copro-PCR. The presence of $T$. gondii genetic material was detected in $16.1 \%$, but $12 \%$ of the samples that tested positive by Copro-PCR were negative in PFT. Samples with discordant results were subjected to a new Copro-PCR with $18 \mathrm{~S}$ marker and a 529, and of the 17 samples, 9 contained T. gondii genetic material. A comparison of the PFT and the molecular methods showed the latter was more sensitive, since it detected $22.1 \%$ while the PFT detected $15.4 \%$. Demonstrating the high sensitivity and specificity of the Copro-PCR, particularly with the association of primers $(k=0.809)$, but also confirms the importance of using molecular techniques in laboratories, since Copro-PCR was able to detect samples considered negative by PFT.
\end{abstract}

Keywords: Toxoplasma gondii, Copro-PCR, cats.

\begin{abstract}
Resumo
Métodos moleculares como a Copro-PCR se destacam no diagnóstico de T. gondii, por serem altamente sensíveis e específicos, podendo distinguir $T$. gondii de outros coccídeos morfologicamente semelhantes. O objetivo foi a detecção da coproprevalência de Toxoplasma gondii por reação em cadeia da polimerase, em 149 amostras fecais de gatos errantes e domiciliados, utilizando-se três marcadores distintos (B5-B6, 18S e 529pb RE). Oocistos de T. gondii/H. hammondi foram detectados em $15,4 \%$ pelos exames parasitológicos de fezes (EPF), e $4 \%$ desses oocistos foram identificados positivamente como $T$. gondii pela Copro-PCR. A presença de material genético de T. gondii foi detectada em $16,1 \%$, mas $12 \%$ das amostras positivas pelo Copro-PCR foram negativas no EPF. As amostras com resultados discordantes foram submetidas a uma nova Copro-PCR com os marcadores 185 e 529 e, das 17 amostras, 9 continham material genético de $T$. gondii. A comparação do EPF com os métodos moleculares mostrou que esse último foi mais sensível, pois detectou $22,1 \%$, enquanto o EPF detectou $15,4 \%$. Isso demonstra a alta sensibilidade e especificidade da Copro-PCR, principalmente com a associação de marcadores $(k=0,809)$; mas também confirma a importância do uso de técnicas moleculares em laboratórios, uma vez que a Copro-PCR foi capaz de detectar amostras consideradas negativas pelo EPF.
\end{abstract}

Palavras-chave: Toxoplasma gondii, Copro-PCR, gatos. 


\section{Introduction}

Toxoplasma gondii is a protozoan of worldwide prevalence, found in every continent and every type of climate. The routes for $T$. gondii include vertical transmission from mother to fetus and horizontal transmission, which involves three life-cycle stages, i.e. ingesting infectious oocysts from the environment or ingesting tissue cysts or tachyzoites which are contained in meat or primary offal (viscera) of many different animals. Transmission may also occur via tachyzoites contained in blood products, tissue transplants, or unpasteurised milk (Tenter et al., 2000). This parasite is transmitted by oocysts present in the feces of stray and domiciled felines, the definitive hosts of this coccidian, which shed millions of immature oocysts in their feces after the primary infection, thereby contaminating the environment. The domestic cat (Felis catus) is able to shed about 10 million oocysts in a single defecation, thus representing an important source of environmental contamination and consequently one of the main routes of transmission of toxoplasmosis (Dubey \& Beattie, 1988; Lindsay et al., 2002; Mancianti et al., 2010). Hence, the presence of stray cats may be a factor that contributes to the high urban prevalence of this parasite (Lima et al., 2018).

Domestic cats also play a major role in the worldwide (human and veterinary) prevalence of $T$. gondii, and their numbers have been increasing considerably in Brazilian households. However, most people are unaware of the zoonotic potential of this species. A contributing factor is that many owners allow their cats to roam freely in the streets, where the animals can ingest prey contaminated with $T$. gondii. Not only domiciled cats but also stray cats, which are considered more susceptible to contact with this parasite, can shed oocysts in the environment after they become infected (Dabritz \& Conrad, 2010; Costa, 2015).

T. gondii oocysts can be detected in cat feces using microscopy through parasitology fecal tests (PFT), bioassays of experimental animals, and via molecular methods (Dubey, 2010; Elmore et al., 2010; Salant et al., 2010). However, the sensitivity of microscopy is too low to distinguish $T$. gondii oocysts from other coccidian oocysts with very similar morphological and morphometric characteristics, e.g., Hammondia hammondi, a parasite commonly found in cats (Barutzki \& Schaper, 2011; Lappin, 2010; Veronesi et al., 2017). In this context, molecular methods such as Copro-PCR stand out in the diagnosis of $T$. gondii, due to their high sensitivity and specificity, which enables them to differentiate between $T$. gondii and other coccids (Burg et al., 1989).

The main molecular markers used in Copro-PCR for T. gondii are the 529-bp repeat element (RE), with 200-300 copies (Costa \& Bretagne, 2012) and the B1 gene, with 35 copies (Burg et al., 1989; Mousavi et al., 2016). Studies suggest that the Copro-PCR that amplifies the 529-bp RE is considered sensitive and specific for the detection of T. gondii in cat feces (Salant et al., 2007, 2010). However, there are few comparative analyses using different genetic markers for the diagnosis of $T$. gondii in fecal samples from cats (Veronesi et al., 2017; Chemoh et al., 2018). This study aims the detection of Toxoplasma gondii copro-prevalence by polymerase chain reaction using three different primers in feces of cats in Goiania, contributing to the use of genetic markers for the diagnosis of $T$. gondii in fecal samples of cats.

\section{Material and Methods}

\section{The study}

This study was approved by the Ethics Committee on Animal Use (CEUA) of the Federal University of Goiás, under protocols no. 054/2013 and 024/2016. 149 cats of varying ages and both sexes were analyzed, from the city of Goiânia, state of Goiás. The animals were divided into two groups: domiciled cats and stray cats. Domiciled cats were considered those that lived in houses or apartments with their owners, without access to the street, and stray cats were captured by the Zoonosis Control Center (ZCC) of Goiânia and by a non-governmental organization (NGO) that protects animals. A total of 149 fecal samples were collected, 65 from stray cats and 84 from domiciled cats. The samples were collected between March 2015 and May 2016. Fecal samples from stray cats were collected directly from the animals' cages before they were wormed, and fecal samples from domiciled cats were collected by their owners. About $10 \mathrm{~g}$ of feces from each cat were stored in universal sterile containers, taking care to exclude samples contaminated with soil.

\section{Analysis of fecal samples}

T. gondii oocysts were identified using the Sheather, Hoffman-Pons-Janer or Lutz (HPJL), and Faust and Willis techniques (Willis, 1921; Sheather, 1923; Hoffman et al., 1934; Faust et al., 1938). The oocysts of T. gondii were 
identified using the measurement of oocyst diameter, according to the protocol described by Simamora et al. (2015). After a parasitology fecal test (PFT) perfomerd in all 149 fecal samples, the same samples were subjected to Copro-PCR for T. gondii, with amplification of the B1 gene using primers B5 and B6, following the protocol proposed by Robert-Gangneux \& Dardé (2012). Samples that yielded contradictory PFT and Copro-PCR (primers B5 and B6) results were analyzed by another Copro-PCR assay, amplifying the B1 gene with the $18 \mathrm{~S}$ marker (Cazenave et al., 1992) and the 529-bp repeat element (Homan et al., 2000).

\section{Copro-PCR employed in the detection of Toxoplasma gondii}

DNA was extracted the fecal samples of the animals. The DNA extraction was performed following the instructions of the kit LightMix ${ }^{\circledR}$, manufacturer ROCHE®, Mannheim, Germany. After adding the lysis buffer, the samples were boiled for 20 minutes and left to rest overnight at $37^{\circ} \mathrm{C}$ to break the oocyst wall. The extraction protocol was then performed the next day.

The polymerase chain reactions (PCR) were carried out in a final volume of $25 \mu \mathrm{L}$ containing $10 \mathrm{mM}$ TRIS HCl (pH 9.0), 3.5mM MgCl2, $0.2 \mathrm{U}$ of Taq DNA Polymerase (Invitrogen), $0.5 \mathrm{mM}$ of each deoxynucleotide (dATP/ dTTP/ dGTP/ dCTP, Sigma Chemical Co., USA®), 50 pmols of each reaction primer (Invitrogen ${ }^{\circledR}$ ) and $5 \mu L$ of DNA template. The reactions were carried out in a MasterCycler Personal thermal cycler. The amplification program consisted of an initial denaturation at $94^{\circ} \mathrm{C}(5 \mathrm{~min})$, followed by 35 cycles of denaturation at $94^{\circ} \mathrm{C}(1 \mathrm{~min})$, annealing at $62^{\circ} \mathrm{C}$ (1 min) and extension at $72{ }^{\circ} \mathrm{C}(1 \mathrm{~min})$, ending with a final extension at $72{ }^{\circ} \mathrm{C}$ for $10 \mathrm{~min}$.

The following primers were used: Toxo-B5 and B6 (Robert-Gangneux \& Dardé, 2012), 18S (Cazenave et al., 1992) and 529 bp (Homan et al., 2000). Mouse peritoneal fluid infected with the RH and ME49 strains and positive stool samples were used as positive control, while previously confirmed negative fecal samples were used as negative control. The PCR amplification products (110 bp) were examined using silver-stained $6 \%$ polyacrylamide gel electrophoresis (Santos et al., 1993).

\section{Statistical analysis}

The agreement between Copro-PCR and the other tests applied was calculated using the Cohen Kappa index $(\mathrm{K})$, using $2 \times 2$ contingency tables. The $\mathrm{k}$ values obtained were interpreted according to the following parameters: $<0.2=$ weak 0.2 to $0.4=$ poor, 0.4 to $0.6=$ regular, 0.6 to $0.8=$ good,$>0.8=$ excellent and $1=$ perfect agreement (Kraemer \& Bloch, 1988; Thrusfield, 2007). Parasitological results were analyzed using the Minitab software.

\section{Results and Discussion}

A total of 149 fecal samples were analyzed, of which $27.5 \%$ (41/149) were positive in one of the tests performed and $72.5 \%$ (108/149) were negative by all the techniques performed. Table 1 lists the positive results obtained by the conventional parasitological and molecular techniques.

In this study, T. gondii/H. hammondi oocysts were detected by means of conventional parasitology fecal testing (PFT) in 15.4\% (23/149) of the samples. Using Copro-PCR (primers B5 and B6), it was found that 4\% (6/149) of the

Table 1. Comparison of conventional parasitological methods and the different primers used in Copro-PCR for the detection of Toxoplasma gondii oocysts in fecal samples from cats in Goiania, Goiás.

\begin{tabular}{|c|c|c|c|}
\hline \multirow{2}{*}{ PFT } & Copro-PCR & Copro-PCR & Positive \\
\hline & (B5 and B6) & (18S and 529pb) & Samples \\
\hline Positive & Positive & Positive & 6 \\
\hline Positive & Negative & Positive & 9 \\
\hline Positive & Negative & Negative & 8 \\
\hline Negative & Positive & Positive & 18 \\
\hline Total & & & 41 \\
\hline
\end{tabular}

PFT: Parasitology Fecal Test; Copro-PCR (B5 and B6): Polymerase chain reaction on fecal samples using primers B5 and B6; Copro-PCR (18S and 529pb): Polymerase chain reaction on fecal samples using the primer 18S and 529-bp repeat element. 
oocysts were really T. gondii, while $11.4 \%$ (17/149) of the oocysts examined under optical microscopy were probably H. hammondi, a species morphologically similar to T. gondii, making it necessary to test the rest of the positive samples by PFT. The methods used here produced congruent positive results in 4\% (6/149) of the samples (Table 1). These data underscore the importance of the differential diagnosis of $H$. hammondi and $T$. gondii, as these coccids share the same definitive hosts (felids) and are morphologically very similar, so that differentiation depends mainly on molecular tools. However H. hammondi is not pathogenic in cats (Dubey \& Sreekumar, 2003; Schares et al., 2008).

On the other hand, the use of Copro-PCR (primers B5 and B6) enabled us to identify the presence of genetic material from $T$. gondii in $16.1 \%$ (24/149) of the analyzed fecal samples. However, $75 \%$ (18/24) of the samples that tested positive by Copro-PCR (primers B5 and B6) tested negative in the conventional parasitology fecal tests (Table 1). Nabi et al. (2018), who analyzed cat feces by microscopy and Copro-PCR, also found discordant results in the methodologies, like this study. They reported that samples testing negative by microscopy were positive by the Copro-PCR technique, demonstrating that molecular tests are more sensitive than microscopy, which is considered the gold standard in the diagnosis of $T$. gondii, since molecular tests detect the parasite's DNA even not detecting oocysts in microscopy (Nabi et al., 2018).

In view of the detection of samples with contradictory results (positive by PFT and negative by Copro-PCR (primers B5 and B6)), these samples were subjected to a new Copro-PCR assay using the markers 18 S and 529-bp repeat element. Of the 17 samples with discrepant results, 9 contained $T$. gondii genetic material were revealed by Copro-PCR using $18 \mathrm{~S}$ marker and the 529-bp repeat element, unlike the markers used in the first Copro-PCR with B5 and B6 (Table 1). These data are in agreement with those reported by Veronesi et al. (2017), who detected positive samples by Copro-PCR using 529-bp as marker, even though they were considered negative by microscopy and by Copro-PCR using B1 as marker (Veronesi et al., 2017).

In this study, a comparison of the molecular methods and conventional parasitological techniques for the detection of $T$. gondii oocysts revealed that the former are more sensitive, detecting $22.1 \%$ (33/149) of the samples, while only $15.4 \%$ (23/149) of the samples tested positive by PFT, as has also been reported by other authors (Dubey, 2010; Salant et al., 2010; Veronesi et al., 2017).

The comparison of the PCR $18 \mathrm{~S}$ and 529 using the $18 \mathrm{~S}$ gene as a comparative test (standard) in the statistical analysis, showed an excellent agreement with $k=0.809$ and when comparing the $18 \mathrm{~S}$ with PTF the agreement was weak, with $k=0.184$, since that molecular techniques are more sensitive (Table 2). The comparison of PTF with PCR $18 \mathrm{~S}$, using PTF as a comparative test (standard) showed a weak agreement, with $\mathrm{k}=0.103$ and when comparing PTF and 529, the agreement was regular, with $k=0.424$ (Table 3). These data demonstrate the importance of confirming the diagnosis of $T$. gondii by molecular techniques with different primer pairs in order to increase the sensitivity of the reaction.

Table 2. Comparison between Copro-PCR for Toxoplasma gondii with primers $18 \mathrm{~S}$ and 529 in fecal samples from cats in GoianiaGoias, using $18 \mathrm{~S}$ as a comparative test (standard).

\begin{tabular}{rccccc}
\hline & Sensitivity & Specificity & PPV & NPV & Kappa \\
\hline 18S with 529 & $100 \%$ & $92.8 \%$ & $72.7 \%$ & $100 \%$ & 0.809 \\
18S with PTF & $25 \%$ & $86.4 \%$ & $26.1 \%$ & $85.7 \%$ & 0.184 \\
\hline
\end{tabular}

PTF: Parasitology Fecal Test; PPV: Positive Predictive Value; NPV: Negative Predictive Value.

Table 3. Comparison between PTF and Copro-PCR techniques for Toxoplasma gondii with primers $18 \mathrm{~S}$ and 529 in fecal samples from cats in Goiania-Goiás, using PTF as a comparative test (standard).

\begin{tabular}{cccccc}
\hline & Sensitivity & Specificity & PPV & NPV & Kappa \\
\hline PTF with 18S & $26.1 \%$ & $85.7 \%$ & $25 \%$ & $86.4 \%$ & 0.103 \\
PTF with 529 & $65.2 \%$ & $85.7 \%$ & $45.5 \%$ & $93.1 \%$ & 0.424 \\
\hline
\end{tabular}

PTF: Parasitology Fecal Test; PPV: Positive Predictive Value; NPV: Negative Predictive Value.

\section{Conclusions}

The results of this study demonstrate the high sensitivity and specificity of the Copro-PCR technique, mainly using the association of primers, and the importance of using molecular techniques in human and veterinary laboratories. Copro-prevalence of $T$. gondii in cats in Goiania by means of PCR using repetitive 529 bp gene is 
around 64\%. Copro-PCR was able to detect samples considered negative by PFT, the gold standard method for the diagnosis of intestinal parasites. Therefore, we propose that Copro-PCR be used as the new gold standard for diagnosing $T$. gondii oocysts in cat fecal samples.

\section{References}

Barutzki D, Schaper R. Results of parasitological examinations of faecal samples from cats and dogs in Germany between 2003 and 2010. Parasitol Res 2011;109(1 Suppl 1): S45-S60. http://dx.doi.org/10.1007/s00436-011-2402-8. PMid:21739375.

Burg JL, Grover CM, Pouletty P, Boothroyd JC. Direct and sensitive detection of a pathogenic protozoan, Toxoplasma gondii, by polymerase chain reaction. J Clin Microbiol 1989; 27(8): 1787-1792. http://dx.doi.org/10.1128/JCM.27.8.1787-1792.1989. PMid:2768467.

Cazenave J, Forestier F, Bessieres MH, Broussin B, Begueret J. Contribution of a new PCR assay to the prenatal diagnosis of congenital toxoplasmosis. Prenat Diagn 1992; 12(2): 119-127. http://dx.doi.org/10.1002/pd.1970120207. PMid:1553357.

Chemoh W, Sawangjaroen N, Nissapatorn V, Sermwittayawong N. Genotyping of Toxoplasma gondii Isolated from cat feces in Songkhla, Southern Thailand. Vet Parasitol Reg Stud Rep 2018; 13: 105-109. http://dx.doi.org/10.1016/j.vprsr.2018.04.005. PMid:31014855.

Costa JM, Bretagne S. Variation of B1 gene and AF146527 repeat element copy numbers according to Toxoplasma gondii strains assessed using real-time quantitative PCR. J Clin Microbiol 2012; 50(4): 1452-1454. http://dx.doi.org/10.1128/JCM.06514-11. PMid:22259209.

Costa RCB. Estudo epidemiológico da coinfecção por Toxoplasma gondii e pelo vírus da imunodeficiência felina em gatos domésticos (Felis catus) em Goiânia, Goiás [dissertation]. Goiânia: Universidade Federal de Goiás; 2015.

Dabritz HA, Conrad PA. Cats and Toxoplasma: implications for public health. Zoonoses Public Health 2010; 57(1): 34-52. http:// dx.doi.org/10.1111/j.1863-2378.2009.01273.x. PMid:19744306.

Dubey JP, Beattie CP. Toxoplasmosis of animals and man. 1st ed. Boca Raton: CRC Press; 1988.

Dubey JP, Sreekumar C. Redescription of Hammondia hammondi and its differentiation from Toxoplasma gondii. Int J Parasitol 2003; 33(13): 1437-1453. http://dx.doi.org/10.1016/S0020-7519(03)00141-3. PMid:14572507.

Dubey JP. Toxoplasmosis of animals and man. 2nd ed. Boca Raton: CRC Press; 2010.

Elmore SA, Jones JL, Conrad PA, Patton S, Lindsay DS, Dubey JP. Toxoplasma gondii: epidemiology, feline clinical aspects, and prevention. Trends Parasitol 2010; 26(4): 190-196. http://dx.doi.org/10.1016/j.pt.2010.01.009. PMid:20202907.

Faust ED, D'Antoni JS, Odom V, Miller MJ, Peres C, Sawitz W, et al. A critical study of clinical laboratory technics for the diagnosis of protozoan cysts and helminth eggs in feces: preliminary communication. Am J Trop Med Hyg 1938; 18(2): 169-183. http:// dx.doi.org/10.4269/ajtmh.1938.s1-18.169.

Hoffman WA, Pons JA, Janer JL. Sedimentation concentration method in schistosomiasis mansoni. PR J Public Health Trop Med 1934; 9: 283-298.

Homan WL, Vercammen M, De Braekeleer J, Verschueren H. Identification of a 200- to 300-fold repetitive 529 bp DNA fragment in Toxoplasma gondii, and its use for diagnostic and quantitative PCR. Int J Parasito/ 2000; 30(1): 69-75. http://dx.doi.org/10.1016/ S0020-7519(99)00170-8. PMid:10675747.

Kraemer HC, Bloch DA. Kappa coefficients in epidemiology: an appraisal of a reappraisal. J Clin Epidemio/ 1988; 41(10): 959-968. http://dx.doi.org/10.1016/0895-4356(88)90032-7. PMid:3193139.

Lappin MR. Doenças infecciosas: infecções polissistêmicas por protozoários. In: Nelson RW, Couto CG, editors. Medicina interna de pequenos animais. 4. ed. Rio de Janeiro: Elsevier; 2010. p. 1367-1370.

Lima JAS, Rezende HHA, Rocha TMDD, Castro AM. Analysis of the accuracy of different laboratory methods for the diagnosis of intestinal parasites from stray and domiciled cats (Felis catus domesticus) in Goiânia, Goiás, Brazil. Braz J Vet Parasitol 2018; 27(1): 95-98. http://dx.doi.org/10.1590/s1984-29612018004. PMid:29641799.

Lindsay DS, Blagburn BL, Dubey JP. Survival of nonsporulated Toxoplasma gondii oocysts under refrigerator conditions. Vet Parasitol 2002; 103(4): 309-313. http://dx.doi.org/10.1016/S0304-4017(01)00554-4. PMid:11777609.

Mancianti F, Nardoni S, Ariti G, Parlanti D, Giuliani G, Papini RA. Cross-sectional survey of Toxoplasma gondii infection in colony cats from urban Florence (Italy).J Feline Med Surg 2010; 12(4): 351-354. http://dx.doi.org/10.1016/j.jfms.2009.09.001. PMid:19811938.

Mousavi M, Saravani R, Jafari Modrek M, Shahrakipour M, Sekandarpour S. Detection of Toxoplasma gondii in Diabetic Patients Using the Nested PCR Assay via RE and B1 Genes. JundishapurJ Microbio/ 2016; 9(2): e29493. http://dx.doi.org/10.5812/jjm.29493. PMid:27127588. 
Nabi H, Rashid MI, Islam S, Bajwa AA, Gul R, Shehzad W, et al. Prevalence of Toxoplasma gondii oocysts through Copro-PCR in cats at Pet Center (UVAS), Lahore, Pakistan. J Pak Med Assoc 2018; 68(1): 115-118. PMid:29371731.

Robert-Gangneux F, Dardé ML. Epidemiology of and diagnostic strategies for toxoplasmosis. Clin Microbiol Rev 2012; 25(2): 264296. http://dx.doi.org/10.1128/CMR.05013-11. PMid:22491772.

Salant H, Markovics A, Spira DA, Hamburger J. The development of a molecular approach for coprodiagnosis of Toxoplasma gondii. Vet Parasitol 2007; 146(3-4): 214-220. http://dx.doi.org/10.1016/j.vetpar.2007.02.022. PMid:17395378.

Salant H, Hamburger J, Spira DT. A comparative analysis of coprologic diagnostic methods for detection of Toxoplasma gondii in cats. Am J Trop Med Hyg 2010; 82(5): 865-870. http://dx.doi.org/10.4269/ajtmh.2010.09-0635. PMid:20439968.

Santos FR, Pena SDJ, Epplen JT. Genetic and population study of a Y-linked tetranucleotide repeat DNA polymorphism with a simple non-isotopic technique. Hum Genet 1993; 90(6): 655-656. http://dx.doi.org/10.1007/BF00202486. PMid:8444472.

Schares G, Vrhovec MG, Pantchev N, Herrmann DC, Conraths FJ. Occurrence of Toxoplasma gondii and Hammondia hammondi oocysts in the faeces of cats from Germany and other European countries. Vet Parasitol 2008; 152(1-2): 34-45. http://dx.doi. org/10.1016/j.vetpar.2007.12.004. PMid:18226453.

Sheather AL. The detection of intestinal protozoa and mange parasites by a floatation technique. J Comp Pathol Ther 1923; 36: 266-275. http://dx.doi.org/10.1016/S0368-1742(23)80052-2.

Simamora ATAJ, Suratma NA, Apsari IAP. Isolasi dan Identifikasi Oosista Toxoplasma gondii pada Feses Kucing dengan Metode Pengapungan Gula Sheater. Ind Med Vet 2015; 4(2): 88-96.

Tenter AM, Heckeroth AR, Weiss LM. Toxoplasma gondii: from animals to humans. Int J Parasitol 2000; 30(12-13): 1217-1258. http://dx.doi.org/10.1016/S0020-7519(00)00124-7. PMid:11113252.

Thrusfield M. Veterinary epidemiology. Oxford: Blackwell Science; 2007.

Veronesi F, Santoro A, Milardi GL, Diaferia M, Morganti G, Ranucci D, et al. Detection of Toxoplasma gondii in faeces of privately owned cats using two PCR assays targeting the B1 gene and the 529-bp repetitive element. Parasitol Res 2017; 116(3): 1063-1069. http://dx.doi.org/10.1007/s00436-017-5388-z. PMid:28127718.

Willis HHA. A simple levitation method for the detection of hookworm ova. Med J Aust 1921; 2(18): 375-376. http://dx.doi. org/10.5694/j.1326-5377.1921.tb60654.x. 